\title{
Pembelajaran PPKn dengan Model VCT Bermuatan Nilai Karakter Meningkatkan Kompetensi Pengetahuan Siswa
}

\author{
I Wayan Wira Astawa1', Made Putra², I.B Gede Surya Abadi³ \\ 1,2,3Program Studi Pendidikan Guru Sekolah Dasar, Universitas Pendidikan Ganesha \\ Singaraja, Indonesia \\ Email: wira3rd@gmail.com , putra.made3112@gmail.com , idabagusgedesurya.abadi@undiksha.ac.id
}

\begin{abstract}
Abstrak
Kurang optimalnya hasil kompetensi pengetahuan PPKn siswa akibat kurangnya penggunaan model pembelajaran atau metode yang variatif sehingga membuat peserta didik menjadi bosan ketika pembelajaran berlangsung menjadi salah satu alasan penelitian ini dilakukan. Penelitian ini bertujuan untuk menganalisis pengaruh model pembelajaran VCT bermuatan nilai karakter terhadap kompetensi pengetahuan PPKn kelas V Sekolah Dasar. Penelitian ini merupakan penelitian eksperimen semu dengan menggunakan desain penelitian "Nonequivalent Control Group Design". Populasi dalam penelitian in adalah seluruh siswa kelas V SD dengan jumlah 324 siswa. Pengambilan sampel dilakukan dengan teknik simple random sampling. Sampel penelitian ini berjumlah 44 orang untuk kelas eksperimen dan berjumlah 44 orang untuk kelas kontrol. Metode pengumpulan data yang digunakan yaitu metode tes dalam bentuk tes pilihan ganda yang sudah divalidasi. Data yang telah dikumpulkan dianalisis dengan analisis statistik deskriptif dan analisis statistik inferensial menggunakan rumus uji-t. Hasil penelitian ini menunjukkan bahwa terdapat perbedaan kompetensi pengetahuan PPKn antara siswa yang dibelajarkan menggunakan model pembelajaran VCT bermuatan nilai karakter dan siswa yang menggunakan model pembelajaran konvensional. Hal ini ditunjukkan dengan nilai thitung $>$ ttabel $(8,468>1,988)$ dengan taraf signifikansi $5 \%$. Sehingga H1 diterima. Berdasarkan hasil penelitian tersebut dapat disimpulkan bahwa model pembelajaran VCT bermuatan nilai karakter berpengaruh terhadap kompetensi pengetahuan PPKn. Model ini bisa digunakan guru dalam menciptakan suasana belajar yang menyenangkan sehingga dapat memberikan kontribusi yang baik dalam kegiatan pembelajaran..
\end{abstract}

Kata kunci: VCT, Nilai Karakter, PPKn

\begin{abstract}
Less optimal learning outcomes PPKn students use different learning models or methods make students become bored learning compilation is one of the reasons this research was conducted. This study tries to analyze the VCT learning model with character values on the knowledge competence of PPKn grade $V$ in elementary schools. This research is an experimental study with the research design "Nonequivalent Control Group Design". The population in this study were all fifth grade elementary school students with 324 students. Sampling is done by simple random sampling technique. This research sample supports 44 people for the experimental class and tries 44 people for the control class. The data collection method used is a test method in the form of a multiple choice test that has been validated. Data collected were analyzed by descriptive statistical analysis and inferential statistical analysis using t-test statistics. The results showed differences in PPKn knowledge between students who were taught using the VCT learning model with character values and students who used conventional learning models. This discusses the value of tcount> ttable (8.468> 1.988) with a significance level of $5 \%$. Receive $\mathrm{H} 1$ received. Based on the results of this study it can be concluded that the VCT learning model is loaded with character values to the PPKn knowledge competence. This model can be used by teachers in creating fun learning so that it can provide good learning in learning activities.
\end{abstract}

Keywords: VCT, Character Value, PPKn 


\section{Pendahuluan}

Pendidikan dalam arti luas yaitu setiap pendidikan maupun pengalaman yang terdapat dalam efek formatif pada pikiran, karakter maupun kemampuan pada fisik setiap individu. Wening (2012) mengemukakan bahwa pembangunan karakter yang berdasar nilai-nilai moral kemanusiaan sangat diperlukan setiap individu ataupun masyarakat melalui adanya proses pendidikan nilai. Sehingga pengembangan pendidikan karakter sangat diperlukan untuk mempersiapkan generasi bangsa yang memiliki rasa nasionalisme dan cinta tanah air yang tinggi. Menurut Suganti (2017) PPKn dalam pelajaran wajib menitikberatkan ranah afektif maupun sikap kepada anak didik. Menurut Tyas \& Mawardi (2016) bahwa inti dari pembelajaran PKn adalah penanaman nilai-nilai dan moral dalam diri siswa. Namun menurut Sudirman (2019) PPKn ialah pendidikan yang mencakup warga negara dan pada hakikatnya dalam penerapannya berkaitan erat dengan nilai maupun moral sesuai dasar negara. Siswinarti (2019) Menyatakan perilaku siswa sebagai seorang individu maupun masyarakat atau warga negara akan dapat memahami secara utuh nilai yang terkandung pada Pancasila melalui Pendidikan Kewarganegaraan. Minawati \& Suryana (2019) juga berpendapat melalui proses maupun pengembangan pembelajaran PPKn yang menyenangkan tentu dapat membuat siswa tertarik hingga lebih mudah saat memahami pembelajaran di sekolah. Tujuan dari pelajaran PPKn adalah sebagai usaha dalam menghayati maupun mewujudkan nilai-nilai dalam kehidupan maupun nilai-nilai Pancasila dalam meningkatkan kualitas dari siswa (Wahana \& Mayasari, 2017). Sesuai dengan tujuan tersebut pelajaran PPKn sangat penting dikuasai oleh anak didik, untuk membentuk kepribadian mereka menjadi individu yang teladan dan berguna baik bagi masyarakat ataupun bangsa dan negara sesuai dengan nilai-nilai yang terkandung dalam Pancasila. Maka dari itu adanya pelajaran PPKn memprioritaskan penerapan nilai-nilai bangsa pada kehidupan nyata berupa tindakan dan perilaku (Fauzi dkk, 2013). Hal ini juga di dukung oleh pendapat Sariani dkk (2016) yang menyatakan bahwa pembelajaran PKn sangat baik diterapkan dalam mengamalkan nilai-nilai moral Pancasila untuk membentuk warga negara.

Di Sekolah Dasar pelajaran PPKn adalah salah satu pelajaran yang wajib untuk siswa dalam menyiapkan pribadi yang dapat bertanggung jawab dalam memajukan dan mempertahankan keutuhan bangsa dimasa mendatang dari persaingan bersama antar negara-negara lainnya. Pembelajaran PPKn di tingkat SD juga bertujuan sebagai proses pembelajaran antara guru dan siswa yang baik sehingga dapat membentuk generasi-generasi bangsa seutuhnya yang diharapkan dapat membangun karakter bangsa dan bernegara berlandaskan UUD 1945, Pancasila maupun norma yang terdapat di masyarakat. Maka dari itu dengan adanya pelajaran PPKn diharapkan dapat berkembangnya perubahan sikap maupun moral perilaku yang mengarah kepada karakter bangsa. Sehingga salah satu keberhasilan yang dirasakan masyarakat dengan adanya PPKn yaitu dengan berkembangnya perubahan sikap maupun moral perilaku yang mengarah kepada karakter bangsa. Hal ini sependapat dengan Juwita (2017) yang menyatakan bahwa baik visi, misi dan tujuan pembelajaran PKn merupakan pemahaman mengenai konsep-konsep yang akan membantu siswa untuk membinakan perilaku etika sopan santun, seperti konsep tentang nilai, moral, dan etika, konsep tentang berbagai pendekatan, model pendidikan nilai, dan model pembelajaran lainnya, serta media pembelajaran yang akan mendukung proses pembinaan etika sopan santun.

Namun pada kenyataannya banyak siswa yang belum menguasai pelajaran PPKn dikarenakan pelajaran PPKn yang dianggap sulit dan membosankan dengan cakupan materi yang luas dan padat. Hal ini dapat dilihat dari temuan hasil observasi bersama guru kelas $\mathrm{V}$ yang dilaksanakan pada tanggal 28 dan 29 Oktober 2019 di Sekolah Dasar yang berada pada Gugus Jendral Sudirman, Kecamatan Denpasar Selatan tahun ajaran 2019/2020 terdapat banyak anak didik yang mendapatkan hambatan dalam menguasai pelajaran muatan PPKn dan banyaknya anak didik yang mendapat nilai yang kurang maksimal pada kompetensi pengetahuan PPKn. Adapun faktor-faktor tersebut diantaranya: 1) Kurangnya penggunaan model pembelajaran atau metode yang variatif sehingga membuat peserta didik menjadi 
bosan ketika pembelajaran berlangsung; 2) Banyaknya siswa kurang fokus dalam menerima pembelajaran dan sikap tegas kepada peserta didik sehingga peserta didik merasa acuh ketika kurang minat pada pembelajaran berlangsung; 3) Kurangnya minat belajar dan semangat pada muatan PPKn.

Keadaan seperti yang telah dipaparkan diatas jika terus dilakukan maka akan mempengaruhi hasil kompetensi pengetahuan siswa. Saat menyampaikan pembelajaran, pendidik tidak hanya menggunakan metode konvesional yang dilakukan sehari-hari sehingga membuat siswa terkesan bosan saat pembelajaran selain itu pembelajaran konvensional mengakibatkan siswa sangat tergantung pada guru, dan hal ini dapat mengakibatkan proses pembelajaran kurang optimal (Putriani dkk, 2017). Untuk mengatasi hambatan tersebut tentunya pendidik juga dapat mengenakan model pembelajaran inovatif dan kreatif dalam memadukan materi pembelajaran sehingga proses dari pembelajaran tersebut menjadi aktif sehingga siswa tidak jenuh saat pembelajaran berlangsung. Pada saat proses belajar mengajar tentu terapat banyak model pembelajaran aktif, inovatif, maupun juga kreatif sehingga dapat digunakan oleh guru dalam mengembangkan materi dan juga proses pembelajaran. Model pembelajaran pada dasarnya ialah sebuah pedoman/acuan bagi guru dalam merancang kegiatan pembelajaran yang cocok untuk mencapai tujuan pembelajaran dari materi/konsep yang akan dipelajari (D. R. Permatasari, 2017). Salah satu model pembelajaran yang dapat diterapkan dalam proses pembelajaran yaitu model pembelajaran VCT dengan bermuatan nilai karakter.

Model pembelajaran inovatif yang bisa digunakan yaitu model pembelajaran VCT atau yang lebih sering dikenal dengan teknik mengklarifikasi nilai. Pembelajaran model VCT ialah suatu cara pendidikan nilai yang meminta siswa agar memilih, maupun menganalisa suatu permaslahan kemudian siswa/siswi memutuskan sikap mandiri mengenai nilai - nilai yang ingin diperjuangkannya (Haris \& Gunansyah, 2013). Menurut Agustina (2016) pembelajaran VCT adalah pembelajaran yang melatih siswa dalam berproses menilai pada taraf kehidupan dalam masyarakat kemudian menetapkan acuan maupun pedoman diri siswa. Selain itu, Iftania dan Widayati (2019) menyatakan model pembelajaran VCT yakni model pembelajaran sebagai sarana menunjukkan nilai baik dan selanjutnya akan diterapkan nyata sehari hari. Hal ini juga dinyatakan oleh Rahayudhi dkk (2013) Value Clarification Technique (VCT) merupakan model pembelajaran yang menitikberatkan pada pembinaan nilai. Model pembelajaran VCT dapat membantu siswa dalam mengkaji akibat-akibat yang timbul dalam suatu tindakan dan membantu siswa dalam menggali, menentukan, serta memaparkan suatu nilai yang dianggap baik dalam menghadapi sebuah permasalahan dengan melakukan analisis dan mengkaji nilai yang sudah terdapat dan tertanam dalam diri siswa. Hal ini sejalan dengan pendapat Putra dkk (2014) yang menyatakan penggunaan pembelajaran VCT berupaya menentukan nilai yang ditafsir benar pada permasalahan lewat proses menganalisa nilai diri siswa sehingga mendapat respon efektif antara nilai lama dengan nilai baru yang melalui proses pembelajaran.

Adapun keunggulan dari penerapan pembelajaran VCT menurut Sukmawati (2014) yaitu siswa mampu menggali kemudian memaparkan simpulan materi, mampu meresapi nilai pada sehari hari, mampu mengembangkan potensi diri maupun nilai moral, mampu memberi pengalaman dari sebuah permasalahan, mampu memadukan nilai moral pada diri individu, dan mampu memberi pandangan nilai moral kepada masyarakat. Sejalan dengan hal tersebut, Djahri (dalam Taniredja dkk, 2017) memaparkan VCT dengan keunggulan sebagai pengajaran efektif yaitu: 1) Penanaman nilai moral pada cakupan internal diri; 2) Bisa mengungkapkan pesan dari materi setelah disampaikan kemudian disampaikan dihadapan rekan-rekannya; 3) Memiliki kemampuan mengklarifikasi nilai serta kualitas diri individu, memahami pesan nilai moral dalam kehidupan; 4) Adanya kemampuan mengembangkan potensi pada diri; 5) Bisa menyalurkan pengalaman pelajaran dari berbagai sumber; 6) Dapat meniadakan mengintervensi ataupun memadukan nilai setiap individu; 7) Memeberi pemahaman nilai moral supaya diterima untuk hidup bermoral tinggi. Tujuan dari pembelajaran VCT yaitu membantu siswa/siswi saat mengembangkan, memilih, maupun menganalisa sikap dan nilainilai pada dirinya sendiri. Peserta didik diberi kesempatan dalam menentukan nilai yang 
menurut mereka baik dan ditanam dalam kehidupannya. Dengan demikian, siswa akan menjadi mandiri, dan dapat mengambil keputusan dalam kehidupannya (Khairunnisa, 2019). Langkah-langkah model pembelajaran VCT menurut Jarolimek (dalam Taniredja dkk, 2017) dibagi ke dalam 7 tahapan dalam 3 tingkatan yang dipaparkan pada tabel 1 .

Tabel 1.3 tingkatan model VCT

\begin{tabular}{|c|c|c|c|}
\hline Tingkat & 1. & a. & $\begin{array}{l}\text { Menentukan secara bebas setiap kesempatan dapat menentukan pilihan } \\
\text { tepat baqinya secara efesien. }\end{array}$ \\
\hline $\begin{array}{l}\text { Kebebasan } \\
\text { dalam }\end{array}$ & & b. & $\begin{array}{l}\text { Menentukan alternatif dari beberapa alternatif pilihan saat disajikan } \\
\text { melalui analisis yang timbul atas kehendaknya. }\end{array}$ \\
\hline Menentukan & & C. & $\begin{array}{l}\text { Menentukan dalam melakukan pertimbangan sebagai kosekuensi atas } \\
\text { pertimbangannya. }\end{array}$ \\
\hline Tingkat & 2. & a. & $\begin{array}{l}\text { Adanya rasa kagum terhadap nilai yang menjadi kehendaknya, sehingga } \\
\text { menjadi integritas pada dirinya. }\end{array}$ \\
\hline Menghargai & & b. & $\begin{array}{l}\text { Menegaskan nilai setiap individu sebagai kehendaknya dan harus berani } \\
\text { penuh kesadaran menunjukannya kepada lainnya. }\end{array}$ \\
\hline $\begin{array}{l}\text { Tingkat } \\
\text { Berbuat }\end{array}$ & 3. & $\begin{array}{l}\mathrm{a} . \\
\mathrm{b} .\end{array}$ & $\begin{array}{l}\text { Memiliki kemampuan saat mencoba maupun menampilkannya. } \\
\text { Mau berperilaku sesuai nilai kehendaknya, nilai yang menjadi kehendak } \\
\text { itu harus terealisasi sehari-hari. }\end{array}$ \\
\hline
\end{tabular}

Selain menggunakan model pembelajaran VCT, guru juga sangat berperan penting dalam membangun nilai-nilai karakter terhadap peserta didik yang nantinya akan terjun langsung bermasyarakat. Terlebih lagi sistem pelajaran kini terlihat belum terlihat efektif dalam membangun nilai karakter pada bangsa kepada peserta didik. Hal ini bisa dilihat dari adanya degradasi moral yang sedang banyak terjadi seperti kasus narkoba, pelajar yang terpapar radikal, kasus pornografi ataupun pornoaksi, dan degradasi nilai kebangsaan dalam bernegara. Adapun Siska (2018) menyatakan bahwa karakter bangsa Indonesia terkenal dengan hidup bergotong-royong, ramah-tamah, tolong-menolong, hormatmenghormati, sopan-santun, dan sebagainya. Hal ini sejalan dengan pendapat Halidu dkk (2018) bahwa penyelenggaraan pendidikan karakter menjadi satu hal yang multlak dilakukan di jenjang pendidikan manapun, khususnya di jenjang pendidikan dasar.

Daniel Goleman (dalam Adisusilo, 2012), memaparkan bahwa pendidikan nilai pada pendidikan karakter yang saling terkait diantaranya: Disiplin pada diri, Bertanggung jawab, memiliki rasa hormat, mampu menegakan keadilan, memiliki kebranian, sikap kejujuran, adanya kepedulian. Maka dari itu penggunaan model pembelajaran VCT dapat digunakan untuk mengembangkan pembelajaran PPKn dan dapat meningkatkan penguasaan siswa terhadap muatan PPKn serta memberikan pendidikan nilai karakter sehingga dapat meningkatkan kompetensi pengetahuan siswa. Hal ini sejalan dengan pendapat Astiti dkk (2017) bahwa pembelajaran VCT adalah bagian pembelajaran khusus dan dapat diterapkan pada muatan PPKn dalam memberikan pemahaman yang lebih jelas tentang pendidikan nilai. Maka dari itu penggunaan model pembelajaran VCT yang dipadukan dengan muatan nilai karakter merupakan strategi yang tepat dalam pembelajaran PPKn, hal ini dikarenakan dapat memudahkan siswa dalam mencari dan menentukan suatu nilai - nilai karakter pada diri mereka sendiri dalam mengahadapi suatu persoalan melalui proses menganalisis nilai yang sudah ada dan tertanam pada diri siswa. Hal lainnya juga bisa memberikan penanaman konsep nilai yang baik saat dipadukan dengan nilai karakter dalam menghadapi suatu hambatan tertentu dengan melibatkan adanya tindakan-tindakan yang terdapat pada diri siswa yang nantinya menjadi identitas nilai maupun norma pada diri siswa.

Beberapa penelitian yang menemukan bahwa model pembelajaran VCT berpengaruh terhadap kompetensi pengetahuan PPKn yaitu penelitian yang dilakukan oleh Dima Septiari dkk. (2018) dengan judul Pengaruh Model Pembelajaran Value Clarification Technique Berbasis Penilaian Proyek Terhadap Kompetensi Pengetahuan PKn. Penelitian ini menyatakan terdapat pengaruh model pembelajaran VCT terhadap kompetensi pengetahuan PKn siswa kelas IV Sekolah Dasar, hal ini terlihat dari rata-rata kompetensi pengetahuan PKn siswa denga menggunakan model pembelajaran VCT lebih tinggi dari rata-rata kompetensi 
pengetahuan PKn siswa tanpa menggunakan model pembelajaran VCT. Penelitian ini berkaitan dengan penelitian yang akan dilakukan yaitu pada penggunaan model pembelajaran VCT dan kompetensi pengetahuan PPKn. Selanjutnya penelitian yang dilakukan oleh Agustin \& Hamid (2017) dengan judul Pengaruh Model Pembelajaran VCT Terhadap Penalaran Moral Siswa dalam Pembelajaran PKn SD. Penelitian ini menyatakan terdapat pengaruh model pembelajaran VCT terhadap kemampuan penalaran moral siswa pada pembelajaran PKn dilihat dari adanya peningkatan rata - rata skor pada posttest. Penelitian ini berkaitan dengan penelitian yang akan dilakukan yaitu pada penggunaan model pembelajaran VCT dan PKn SD hanya saja penelitian ini mengkaji mengenai moral siswa pada pembelajaran PKn D. Sehingga dari beberapa penelitian tersebut dapat diketahui bahwa model pembelajaran VCT berpengaruh terhadap kompetensi pengetahuan PPKn di SD.

Penelitian ini bertujuan untuk mengetahui pengaruh model pembelajaran VCT bermuatan nilai karakter terhadap kompetensi pengetahuan PPKn siswa kelas V Sekolah Dasar tahun pelajaran 2019/2020. Penelitian ini memiliki perbedaan dengan penelitian yang sudah ada yaitu penelitian ini berinovasi pada muatan nilai karakter. Dengan penerapan model ini diharapkan masalah mengenai kompetensi pengetahuan PPKn di SD Gugus Jendral Sudirman Kecamatan Denpasar Selatan dapat diatasi.

\section{Metode}

Penelitian ini dilaksanakan di kelas V SD Gugus Gugus Jendral Sudirman Kecamatan Denpasar Selatan Tahun Ajaran 2019/2020. Penelitian ini menggunakan desain penelitian eksperimen semu (quasi eksperiment). Rancangan penelitian yang digunakan yaitu desain non equivalent control group design. Pelaksanaan penelitian ini di bagi menjadi 3 tahap prosedur yaitu tahap persiapan, tahap pelaksanaan, dan tahap akhir eksperimen. Adapun uraian dari setiap tahapan yaitu, pada tahap persiapan hal yang dilakukan yaitu menentukan sekolah yang akan menjadi tempat penelitian, melakukan obervasi dan wawancara di sekolah yang ditentukan, menetukan sampel penelitian, menetapkan jadwal penelitian, menentukan materi pembelajaran, membuat RPP, LKS dan Instrumen, mengkonsultasikan instrumen ke dosen pembimbing, dan mengadakan uji coba instrumen. Kemudian pada tahap pelaksanaan yaitu memberikan perlakuan pembelajaran VCT bermuatan nilai karakter di kelas eksperimen dan memberikan perlakukan pembelajaran konvensional di kelas kontrol. Selanjutnya pada tahap akhir eksperimen hal yang dilakukan yaitu melaksanakan posttest pada kelompok eksperimen dan kontrol, menganalisis hasil penelitian, melakukan uji hipotesis, dan membuat laporan.

Pada saat melaksanakan sebuah penelitian harus ditentukan populasi dan sampel yang akan digunakan. Populasi penelitian ini yakni kelas V Gugus Jendral Sudirman Kecamatan Denpasar Selatan tahun ajaran 2019/2020 yang terdiri dari 8 kelas dalam 5 sekolah. Jumlah populasi dalam penelitian ini adalah 324 siswa. Setelah mengetahui populasi dari penelitian yang akan dilakukan, selanjutnya adalah menentukan sampel penelitian. Penentuan sampel penelitian ditentukan dengan menggunakan teknik random sampling. Cara yang digunakan untuk menentukan sampel yaitu dengan cara pengundian kemudian nama kelas $\mathrm{V}$ yang muncul dalam undian tersebut diberi pre test dengan tujuan untuk menyetarakan kedua kelompok. Adapun perolehan uji kesetaraan uji $t$ mendapatkan $t_{\text {hitung }}=0,331$ dan $t_{\text {tabel }}$ pada taraf signifikansi $5 \%$ dan $\mathrm{dk}(\mathrm{n} 1+\mathrm{n} 2-2)=1,99$. Karena $T_{\text {hitung }} \leq \mathrm{T}_{\text {tabel }}$, maka $\mathrm{H}_{0}$ diterima dan kelompok dinyatakan setara. Berdasarkan pengundian tersebut diperoleh sampel dalam penelitian ini adalah kelas V B SDN 6 Sesetan dengan jumlah 44 siswa sebagai kelompok eksperimen dan kelas V SDN 13 Sesetan dengan jumlah 44 siswa sebagai kelompok kontrol.

Penelitian ini memiliki 2 variabel yaitu variabel bebas dan variabel terikat. Variabel bebas pada penelitian ini yaitu model pembelajaran VCT bermuatan pendidikan karakter, sedangkan variabel terikat dalam penelitian ini yaitu kompetensi pengetahuan PPKn.

Metode yang digunakan dalam penelitian ini untuk mengumpulkan data adalah metode tes, dengan jenis tes yaitu tes objektif dengan 4 pilihan jawaban (A, B, C, D). Setiap soal diberikan skor 1 jika dijawab dengan benar dan skor 0 bila siswa tidak menjawab ataupun jawabannya salah. Tes kompetensi pengetahuan yang dikembangkan disesuaikan dengan 
jenjang kemampuan kognitif siswa. Kompetensi dasar yang diukur pada penelitian ini yaitu menelaah keberagaman sosial budaya masyarakat dengan indikator yang digunakan yaitu aspek kognitif revisi dari taksonomi Bloom yang terdiri dari menyebutkan (C1), menjelaskan (C2), menentukan (C3) dan menganalisis (C4) .Kemudian, untuk memastikan instrumen memiliki kualitas yang baik makan dilakukan pengujian instrumen berupa uji validitas oleh pakar yang membidangi PPKn dan juga dilakukan tes uji coba dengan jumlah responden 34 siswa, Dari hasil uji instrumen tersebut diperoleh hasil dari 40 butir tes yang di uji cobakan 35 butir soal dinyatakan valid atau layak digunakan dalam penelitian dan 5 butir soal yang tidak layak digunakan. Adapun kisi-kisi yang digunakan dalam penelitian ini dikembangkan dari kompetensi dasar untuk muatan PPKn yang dikembangkan menjadi 8 indikator yang dibagi menjadi 2 indikator untuk ranah kognitif pada tingkat $C 1,2$ indikator untuk ranah kognitif pada tingkat C2, 2 indikator untuk ranah kognitif pada tingkat C3 dan 2 indikator untuk ranah kognitif pada tingkat $\mathrm{C} 4$.

Metode analisis data yang digunakan pada penelitian ini yakni menggunakan metode analisis statistik deskriptif dan metode analisis statistik inferensial. Analisis statistik deskriptif berfungsi untuk memaparkan serta menyajikan data. Sedangkan analisis statistik inferensial berfungsi untuk menggeneralisasi hasil penelitian yang telah dilaksanakan. Analisis statistik deskriptif yang digunakan pada penelitian ini yaitu mencari mean, standar deviasi, varians, serta untuk menentukan penilaian skala lima. Sedangkan, analisis statistik inferensial digunakan untuk menguji hipotesis menggunakan uji-t (polled varians). Sebelum dilakukan uji hipotesis, diawali terlebih dahulu uji prasyarat yaitu uji normalitas sebaran data dan uji homogenitas sebaran data. Perhitungan uji asumsi dan uji hipotesis dilakukan secara manual menggunakan rumus.

\section{Hasil dan Pembahasan}

Deskripsi data hasil penelitian ini memaparkan perolehan hasil post test kompetensi pengetahuan PPKn kelompok siswa yang mengikuti model VCT bermuatan nilai karakter (eksperimen) dan kelompok siswa yang mengikuti pembelajaran konvensional (kontrol). Rekapitulasi hasil perhitungan statistik deskriptif skor post-test kompetensi pengetahuan PPKn disajikan pada tabel 2.

Tabel 2. Rekapitulasi hasil perhitungan statistik deskriptif skor post-test kompetensi pengetahuan PPKn

\begin{tabular}{ccccccc}
\hline Kelompok & $\mathrm{N}$ & Mean & $\begin{array}{c}\text { Standar } \\
\text { Deviasi }\end{array}$ & Varians & $\begin{array}{c}\text { Skor } \\
\text { minimum }\end{array}$ & $\begin{array}{c}\text { Skor } \\
\text { maksimum }\end{array}$ \\
\hline Eksperimen & 44 & 0,679 & 0,103 & 0,019 & 23 & 28 \\
Kontrol & 44 & 0,438 & 0,128 & 0,017 & 20 & 25 \\
\hline
\end{tabular}

Dilihat dari tabel 2, menunjukan data hasil post-test kompetensi pengetahuan PPKn pada kelompok eksperimen dengan jumlah 44 siswa menunjukkan bahwa skor tertinggi yang diperoleh siswa adalah 28, dan skor terendah adalah 23. Dari skor yang diperoleh tersebut diperoleh Mean 0,679, standar deviasi 0,103, dan varians 0,019. Berdasarkan hasil konversi PAP skala lima diketahui bahwa rata-rata kompetensi pengetahuan PPKn siswa pada kelompok eksperimen berada pada kategori baik. Sedangkan, data hasil post-test kompetensi pengetahuan PPKn pada kelompok kontrol dengan jumlah 44 siswa menunjukkan bahwa skor tertinggi yang diperoleh siswa adalah 25, dan skor terendah adalah 20. Dari skor yang diperoleh tersebut diperoleh Mean 0,438, standar deviasi 0,128, dan varians 0,017 . Berdasarkan hasil konversi PAP skala lima diketahui bahwa rata-rata kompetensi pengetahuan PPKn siswa pada kelompok kontrol berada pada kategori cukup.

Dari data yang diperoleh, Adapun rekapitulasi hasil perhitungan uji asumsi disajikan pada tabel 3. 
Tabel 3. Hasil Perhitungan Uji Asumsi

\begin{tabular}{|c|c|c|c|c|c|c|c|c|}
\hline \multirow[b]{2}{*}{ No } & \multirow[b]{2}{*}{$\begin{array}{l}\text { Kelompok } \\
\text { Data }\end{array}$} & \multicolumn{3}{|c|}{ Uji Normalitas } & \multicolumn{4}{|c|}{ Uji Homogenitas } \\
\hline & & $x^{2}$ & $\begin{array}{c}\text { Nilai Kritis } \\
\text { dengan Taraf } \\
\text { Signifikansi 5\% }\end{array}$ & Status & Varians & $\mathbf{F}_{\text {hitung }}$ & $F_{\text {tabel }}$ & Kesimpulan \\
\hline 1 & $\begin{array}{l}\text { Post-test } \\
\text { Kelompok }\end{array}$ & 0,067 & 0,205 & Normal & 0,0167 & & & \\
\hline 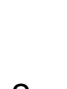 & $\begin{array}{l}\text { Eksperimen } \\
\text { Post-test }\end{array}$ & & & & & 1,532 & 1,660 & Homogen \\
\hline 2 & $\begin{array}{l}\text { Kelompok } \\
\text { Kontrol }\end{array}$ & 0,138 & 0,205 & Normal & 0,0109 & & & \\
\hline
\end{tabular}

Berdasarkan tabel 3 tentang hasil uji asumsis diperoleh uji normalitas yang dilakukan pada kelompok eskperimen diperoleh hasil sebaran data pada taraf signifikansi $5 \%$ untuk $n=$ 44 yang memperoleh nilai tabel Kolmogorov-Smirnov yaitu 0,205 sehingga perbandingan nilai $|\mathrm{Ft}-\mathrm{Fs}|$ maksimum $\leq$ nilai tabel Kolmogorov-Smirnov yaitu 0,067 $<0,205$, yang artinya sebaran data kelompok kelas eksperimen berdistribusi normal. Serta pada kelompok kontrol diperoleh hasil sebaran data pada taraf signifikansi $5 \%$ untuk $n=44$ yang memperoleh nilai tabel Kolmogorov-Smirnov yaitu 0,205 sehingga perbandingan nilai |Ft-Fs| maksimum $\leq$ nilai tabel Kolmogorov-Smirnov yaitu 0,138<0,205, yang artinya sebaran data kelompok kelas kontrol berdistribusi normal. Setelah dilakukan uji normalitas dilanjutkan dengan uji homogenitas varians, berdasarkan uji yang dilakukan didapatkan nilai $F_{\text {tabel }}$ dengan taraf signifikansi $5 \% \mathrm{dk}$ pembilang $=43$ bersama dk penyebut $=43$ yaitu sebesar 1,660 , sedangkan hasil perhitungan diperoleh nilai $F_{\text {hitung }}=1.532$. Ini berarti $F_{\text {hitung }}<F_{\text {tabel }}$ yaitu 1,532 $<1,660$. Maka dari itu pengujian dinyatakan memiliki varians homogen.

Berdasarkan uji asumsi yang telah dilakukan diperoleh hasil bahwa uji normalitas sebaran data dan homogenitas varians memenuhi syarat untuk dilanjutkan dengan uji hipotesis menggunakan uji t (polled varians). Adapun rekapitulasi hasil pengujian hipotesis dalam penelitian ini dapat dilihat pada tabel 4.

Tabel 4. Hasil Uji t.

\begin{tabular}{|c|c|c|c|c|c|c|}
\hline Kelompok & $\mathrm{N}$ & Mean & Varians & $\mathrm{Db}$ & $t_{\text {hitung }}$ & $t_{\text {tabel }}$ \\
\hline Eksperimen & 44 & 0,679 & 0,019 & \multirow{2}{*}{86} & \multirow{2}{*}{8,468} & \multirow{2}{*}{1,988} \\
\hline Kontrol & 44 & 0,438 & 0,017 & & & \\
\hline
\end{tabular}

Berdasarkan hasil perhitungan uji $t$ diperoleh $t_{\text {hitung }}$ sebesar 8,468 . Hasil tersebut kemudian dibandingkan dengan $t_{\text {tabel }}$ yaitu 1,988 dengan taraf signifikansi $5 \%(\mathrm{db}=86)$, sehingga diperoleh hasil bahwa thitung $>t_{\text {tabel }}(8,468>1,988)$. Ini berarti $\mathrm{H}_{0}$ ditolak dan $\mathrm{H}_{1}$ diterima. Jadi terdapat perbedaan signifikan hasil kompetensi pengetahuan PPKn kelas dibelajarkan model VCT bermuatan nilai karakter dengan kelas dibelajarkan secara konvensional kelas V SD Gugus Jendral Sudirman Kecamatan Denpasar Selatan Tahun Pelajaran 2019/2020.

Deskripsi umum pada penelitian ini menyatakan bahwa terdapat perbedaan kompetensi pengetahuan PPKn antara kelompok siswa yang dibelajarkan menggunakan model VCT bermuatan nilai karakter dengan kelompok siswa yang dibelajarkan secara konvensional. Hal ini dapat dilihat dari rata-rata skor kompetensi pengetahuan PPKn siswa yang dibelajarkan menggunakan model VCT bermuatan nilai karakter adalah 0,679 yang berada pada kategori baik. Sementara itu, skor kompetensi pengetahuan PPKn siswa yang dibelajarkan secara konvensional adalah 0, 438 yang berada pada kategori cukup. Selain itu, berdasarkan analisis data menggunakan uji-t diketahui thitung $=8,468$ dan $t_{\text {tabel }}(\mathrm{db}=68$ dan taraf signifikansi $5 \%)=$ 1,988. Hasil perhitungan tersebut menunjukkan bahwa $t_{\text {hitung }}>t_{\text {tabel }}$ sehingga dapat diartikan bahwa terdapat perbedaan antara kelompok siswa yang dibelajarkan dengan model VCT 
bermuatan nilai karakter dengan kelompok siswa yang dibelajarkan secara konvensional di kelas V SD Gugus Jendral Sudirman Kecamatan Denpasar Selatan tahun ajaran 2019/2020. Perbedaan perolehan kompetensi pengetahuan PPKn diantara kelas eksperimen dengan kelas kontrol disebabkan karena adanya tindakan saat diberikan baik pada langkah pembelajaran maupun proses pembelajaran yang berbeda diantara kedua kelompok serta dipengaruhi oleh beberapa faktor berikut.

Pertama, model pembelajaran VCT memudahkan siswa dalam mengklarifikasi/menggali dan mengungkapkan isi pesan materi yang disampaikan, dan selanjutnya akan memudahkan bagi guru untuk menyampaikan makna/pesan nilai/moral. Pada hal ini, siswa dituntut untuk mengembangkan nilai - nilai yang ada pada diri mereka sendiri dalam menghadapi suatu permasalahan melalui proses menganalisis yang kemudian nilai - nilai tersebut ditanamakan secara sadar dalam diri mereka sendiri sehingga dapat menyampaikan maupun menilai kualitas pada orang lain serta memahami nilai dalam kehidupan nyata dalam sehari-hari. Hal ini diperkuat dengan temuan Hakim dkk (2018) yang berpendapat bahwa salah satu fungsi dari adanya pembelajaran VCT ialah menanamkan suatu nilai kepada siswa melalui cara yang rasional dan diterima siswa sebagai milik pribadinya.

Kedua, pada dasarnya saat proses pembelajaran siswa berperan aktif bersama temannya dalam menggali dan menemukan nilai - nilai moral yang mereka temukan dalam menghadapi suatu permasalahan melalui diskusi kelompok maupun secara individu yang memungkinkan siswa secara mandiri untuk membina dan menanamakan nilai dan moral pada ranah internal side. Hal ini menunjukan peran aktif siswa secara mandiri dalam mengembangkan kemampuannya dalam menyelesaikan permasalahan melalui proses analisis nilai yang sudah ada pada diri mereka yang kemudian nilai - nilai tersebut ditanamkan pada diri mereka sendiri. Berlangsungnya proses pembelajaran guru berperan dalam merencanakan, membina dan mengatur kelompok sebagai sarana fasilitator agar tidak keluar dari ruang lingkup pembelajaran yang sedang dilaksanakan. Hal ini sejalan dengan pendapat D. Permatasari \& Sani Safitri (2018) bahwa model VCT mampu memotivasi peserta didik untuk mempunyai keterampilan atau kemampuan menentukan nilai - nilai hidup yang tepat sesuai dengan tujuan hidupnya dalam hal ini siswa di ajak untuk values problem solving, diskusi, dialog dan persentasi terhadap suatu permasalahan yang mempunyai penilaian diri yang tinggi. Dengan demikian, peserta didik semakin mandiri, semakin mampu mengambil keputusan sendiri dan mengarahkan hidupnya sendiri, tanpa campur tangan yang tidak perlu oleh pihak lain.

Ketiga, memberikannya kesempatan siswa berinovasi dalam mengembangkan rasa ingin tahu, berfikir kreatif maupun kreatif dalam memecahkan suatu permasalahan melalui nilai - nilai karakter yang sudah ada. Dalam hal ini siswa diberikan kebebasannya seluas-luasnya kepada siswa untuk terlibat secara langsung dan aktif dalam proses pembelajaran mulai dari perencanaan memilih suatu permasalahan yang diberikan oleh guru hingga memecahkannya secara berkelompok maupun individu melalui nilai - nilai yang sudah ada dalam diri mereka sendiri yang kemudian nilai tersebut ditanamkan pada diri mereka sendiri. Hal ini menunjukan bahwa siswa dapat berinovasi dan berfikir kritis sesuai kehendak mereka dalam menghadapi permasalahan yang ada melalui nilai - nilai kemudian guru membimbing jawaban dari setiap kelompok maupun individu yang memungkinkan siswa dapat bertukar pikiran terhadap siswa lainnya. Hal ini didukung dengan temuan Sutiyono dkk (2016) yang menunjukan bahwa pembelajaran VCT merupakan salah satu pendekatan yang paling efektif dalam menenamkan dan memilih serta mengkaji nilai secara mendalam dan dalam penyajiannya dapat disesuaikan dengan karakteristik dan kebutuhan peserta didik.

Selain membuat siswa secara mandiri dalam mengembangkan produktivitas dan kreativitasnya sendiri dalam mencari nilai-nilai pada masalah yang diberikan dan dipelajarinya saat pembelajaran. Pembelajaran VCT bermuatan nilai karakter mengedepankan secara sederhana tahapan dalam pembelajaran diantara nya yang pertama ialah kebebasan dalam menentukan secara bebas setiap kesempatan dapat menentukan pilihan tepat baginya secara efesien, kebebasan menentukan alternatif dari beberapa alternatif pilihan saat disajikan melalui analisis yang timbul atas kehendaknya, dan kebebasan dalam menentukan dalam melakukan pertimbangan sebagai kosekuensi atas pertimbangannya. Kedua, yaitu Sikap 
menghargai seperti adanya rasa kagum terhadap nilai yang menjadi kehendaknya, sehingga menjadi integritas pada dirinya dan menegaskan nilai setiap individu sebagai kehendaknya dengan penuh percaya diri serta kesadaran menunjukannya kepada lainnya. Ketiga, yakni berbuat layaknya memiliki kemampuan saat mencoba maupun menampilkannya dan mau berperilaku sesuai nilai kehendaknya, nilai yang menjadi kehendak itu harus terealisasi seharihari. Hal ini didukung oleh Wijayanti (2013) yang berpendapat bahwa teknik klarifikasi nilai apabila diterapkan sesuai tahapan tersebut dalam pembelajaran maka dapat meningkatkan kemampuan siswa untuk: 1) memilih, memutuskan, mengkomunikasikan, mengungkapkan gagasan, keyakinan, nilainilai dan perasaannya;2) berempati atau memahami perasaan orang lain dan melihat sudut pandang orang lain; 3) memecahkan masalah; 4) menyatakan sikap setuju atau tidak setuju, menolak atau menerima pendapat orang lain; 5) mempunyai pendirian dalam mengambil keputusan, menginternalisasikan dan bertingkah laku sesuai dengan nilai yang telah dipilih.

Berbeda halnya dengan kelas kontrol yang dibelajarkan dengan model pembelajaran konvensional. Dalam pembelajaran guru lebih banyak yang mendominasi kelas dengan penyampaian materi yang dilakukan dengan cara ceramah, tanya jawab, dan penugasan secara terus menerus sehingga cederung akan membuat siswa terkesan bosan dalam mengikuti pembelajaran. Maulida dkk (2019) menyatakan metode konvensional merupakan suatu proses pembelajaran biasa yang paling sering dilakukan oleh guru-guru di sekolah. Pada pembelajaran ini guru memberikan penerangan atau penuturan secara lisan kepada sejumlah siswa. Metode pembelajaran seperti ini tentu kurang dalam memaksimalkan potensi yang dimiliki siswa baik dari segi produktivitasnya maupun kreativitasnya, maka dari itu pada pelaksanaan penelitian ini ditemukan bahwa penerapan model pembelajaran VCT bermuatan nilai karakter dapat dikatakan sebagai salah satu pembelajaran yang bermakna dan unggul bagi siswa sehingga dapat meningkatkan kompetensi pengetahuan PPKn siswa. Hal ini sejalan dengan pendapat Sudirman (2019) yang menunjukan bahwa model pembelajaran VCT adalah suatu model untuk menganalisis nilai, aplikasinya dalam pembelajaran dimulai dari pemberian stimulus yang berisi konflik nilai moral yang membingungkan yang dapat melabilkan keseimbangan dalam proses kognitif siswa, kemudian siswa terlibat dalam menyelidiki problema, mendiskusikan problema dalam kelompok kecil/kelas dengan pola tuntunan dari guru dan akhirnya siswa merumuskan pandangan-pandangannya.

Temuan-temuan tersebut memberikan implikasi yaitu untuk meningkatkan kompetensi pengetahuan PPKn, model pembelajaran VCT bermuatan nilai karakter dapat digunakan guru dalam menciptakan suasana belajar yang bermakna dan unggul sehingga dapat memberikan kontribusi yang baik dalam kegiatan pembelajaran.

Hasil penelitian ini juga diperkuat dengan penelitian yang sudah dilaksanakan oleh : (a) Selly Lindayani dkk (2019) yang menyebutkan adanya pembelajaran VCT bermuatan nilai karakter berpengaruh baik kepada hasil kompetensi pengetahuan PPKn anak didik. (b) Agustini dkk (2015) menunjukkan bahwa terdapat perbedaan signifikan hasil belajar ranah afektif PKn antara kelompok siswa yang mengikuti pembelajaran dengan menggunakan model pembelajaran VCT dengan kelompok siswa yang mengikuti pembelajaran dengan model pembelajaran konvensional pada mata pelajaran PKn kelas V SD di Gugus III Kecamatan Dawan, Kabupaten Klungkung tahun pelajaran 2014/2015. Dengan demikian penerapan pembelajaran VCT bermuatan nilai karakter berpengaruh positif dan signifikan terhadap hasil kompetensi pengetahuan PPKn.

\section{Simpulan}

Berdasarkan hasil analisis data kompetensi pengetahuan PPKn yang telah dilakukan pada kelompok yang dibelajarkan dengan model VCT bermuatan nilai karakter dan kelompok yang dibelajarkan secara konvensioanl diperoleh hasil bahwa $t_{\text {hitung }}$ lebih besar dari $t_{\text {tabel }}$ yaitu $8,468>1$, 988. Selain itu, perbedaan skor rata-rata yang diperoleh oleh siswa yang dibelajarkan menggunakan model VCT bermuatan nilai karakter adalah 0,679 sedangkan siswa yang dibelajarkan secara konvensional adalah 0,438 . Sehingga, hal ini menunjukan bahwa terdapat perbedaan yang signifikan Kompetensi pengetahuan PPKn antara siswa yang 
dibelajarkan dengan model VCT bermuatan nilai karakter dengan siswa yang dibelajarkan secara konvensional di kelas V SD Gugus Jendral Sudirman Kecamatan Denpasar Selatan Tahun Ajaran 2019/2020. Dengan demikian bisa disimpulkan bahwa pembelajaran VCT bermuatan nilai karakter berpengaruh terhadap kompetensi pengetahuan PPKn kelas V SD Gugus Jendral Sudirman Kecamatan Denpasar Selatan tahun ajaran 2019/2020.

Adapun beberapa saran diajukan sebagai tindak lanjut penelitian ini yaitu 1) Kepada Guru, harapan terhadap guru menerapkan variasi pembelajaran di kelas dengan menerapkan pembelaaran inovatif seperti VCT bermuatan nilai karakter serta guru juga bisa memadukannya dengan media pembelajaran. 2) Kepada Sekolah, pihak sekolah diharapkan mampu untuk memanfaatkan hasil penelitian sebagai acuan dalam mengembangkan variasi dalam proses pembelajaran dengan memfasilitasi dan memberikan pelatihan tentang variasi dalam proses pembelajaran seperti penerapan model dan penggunanaan media pembelajaran. 3) Kepada Peneliti Lain, bagi peneliti lain agar mampu menemukan variasi pembelajaran kreatif menyesuaikan pada kurikulum 2013 agar dapat memotivasi murid-murid sehingga lebih bersemangat saat belajar mengajar.

\section{Daftar Pustaka}

Adisusilo, S. (2012). Pembelajaran Nilai Karakter. PT. RajaGrafindo Persada.

Agustin, N., \& Hamid, S. I. (2017). Pengaruh Model Pembelajaran VCT Terhadap Penalaran Moral Siswa dalam Pembelajaran PKn. Jurnal Moral Kemasyarakatan, 2(1), 59-74.

Agustina, M. (2016). Perbandingan Model Vct Dan Model Moral Reasoning Untuk Meningkatkan Keterampilan Sosial Dengan Memperhatikan Konsep Diri Siswa Pada Pembelajaran IPS. IOSR Journal of Economics and Finance, 3(1), 56.

Agustini, N. L. P. E., Renda, N. T., \& Murda, I. N. (2015). Pengaruh model pembelajaran VCT terhadap hasil belajar ranah afektif mata pelajaran PKn siswa. Mimbar PGSD Undiksha, $3(1)$.

Astiti, N. K. A., Suarjana, I. M., \& Arini, N. W. (2017). Pengaruh Model Pembelajaran VCT Berbantuan Media Power Point Terhadap Hasil Belajar PKn Siswa Kelas V SD Gugus V Kecamatan Buleleng. Journal PGSD Universitas Pendidikan Ganesha, 5(2), 1-10.

Dima Septiari, N. L. P., Sri Asri, I. G. A. A., \& Suniasih, N. W. (2018). Pengaruh Model Pembelajaran Pair Check Berbasis Penilaian Kinerja Terhadap Kompetensi Pengetahuan Pkn Siswa Kelas Iv. Mimbar IImu, 23(1), 67-75.

Fauzi, fadil yudia, Arianto, I., \& Solihatin, E. (2013). Peran Guru Pendidikan Pancasila Dan Kewarganegaraan Dalam Upaya Pembentukan Karakter Peserta Didik Fadil Yudia Fauzi, Ismail Arianto, Etin Solihatin) Program Studi PPKN FIS Universitas Negeri Jakarta. Jurnal Ppkn Unj Online, 1(2013), 2.

Hakim, Z. R., Taufik, M., \& Atharoh, M. (2018). Penerapan Model Pembelajaran Vct (Value Clarification Technique) Terhadap Kemampuan Pemecahan Masalah Siswa Pada Mata Pelajaran Ips Di Sekolah Dasar Negeri Cimanis 2 Sobang Pandeglang. JPPGuseda / Jurnal Pendidikan \& Pengajaran Guru Sekolah Dasar,

Halidu, S., Dehi, P. M., Rahmat, A., Mirnawati, M. (2018). Implementasi Pendidikan Karakter Siswa Sekolah Dasar di Indonesia. Dk, 4(23), 1689-1699.

Haris, F., \& Gunansyah, G. (2013). Penerapan Model Pembelajaran Vct ( Value Clarification Technique ). Jpgsd, 01(5), 1-11.

Iftania, Widayati, S. (2019). Penerapan Model Pembelajaran Value Clarification Technique 
Untuk Meningkatkan Hasil Belajar Ppkn Pada Siswa Kelas Iv Sd Ummul Quro' Kecamatan Gunungpati Kota Semarang. Undaris Ungaran, 1-11.

Juwita, P. (2017). Pembinaan Etika Sopan Santun Peserta Didik Kelas V Melalui Pembelajaran Pendidikan Kewarganegaraan. Jurnal IImiah Pendidikan Guru Sekolah Dasar, 10(1), 27-36.

Khairunnisa. (2019). Upaya Meningkatkan Hasil Belajar Siswa Pada Mata Pelajaran Pkn Materi Hak Dan Kewajiban Warga Negara Melalui Strategi Pembelajaran Value Clarificate Technique (Vct) Pada Siswa Kelas Iv Mis Mutiara Sei Mencirim Tahun Ajaran 2018/2019. Problem Set 2, 23(3), 2019.

Maulida, N., Sunardjo, \& Novitasari, A. T. (2019). Pengaruh Metode Pembelajaran Contextual Teaching And Learning ( CTL ) Dan Konvensional Terhadap Hasil Belajar Siswa Kelas VII Pada Pelajaran PKn MTs Nurul Karomah Kecamatan Galis Kabupaten Bangkalan. 9924, 195-202.

Minawati, A. A., \& Suryana, Y. (2019). Penanaman Nilai-Nilai Sila III Pancasila Melalui Penerapan Model Pembelajaran Berbasis Masalah untuk Membangun Karakter Siswa Sekolah Dasar. PEDADIDAKTIKA: Jurnal IImiah Pendidikan Guru Sekolah Dasar, 6(1), 195-202.

Permatasari, D. R. (2017). Pengaruh Model Pembelajaran Value Clarification Technique (Vct) Tipe Percontohan Terhadap Prestasi Belajar Dan Tanggung Jawab Materi Globalisasi. Dinamika Jurnal IImiah Pendidikan Dasar, 9(1), 23-28.

Permatasari, D., \& Sani Safitri, H. (2018). Pengaruh Penerapan Model Pembelajaran Vct (Value Clarification Technique) Terhadap Afeksi Peserta Didik Pada Mata Pelajaran Sejarah Di Kelas X Sma Negeri 16 Palembang Devi. 7(1).

Putra, I P. E. P., Sulastri, M., Wirya, N. (2014). Pengaruh Model Pembelajaran Value Clarification Teenique (Vct) Terhadap Hasil Belajar Pkn Siswa Kelas V. MIMBAR PGSD Undiksha, 2(1).

Putriani, N. P. D., Mahadewi, L. P. P., Rati, N. W. (2017). Pengaruh Model Pembelajaran Value Clarification Technique (Vct) Bermediakan Video Terhadap Hasil Belajar Pkn Siswa Kelas V. MIMBAR PGSD Undiksha, 5(2).

Rahayudhi, N. P. Y., Agung, A. A. G., Tastra, I. D. K. (2013). Pengaruh Model Pembelajaran Vct Berbantuan Media Microsoft Powerpoint Terhadap Prestasi Belajar PKn. MIMBAR PGSD Undiksha, 1(1).

Sariani, N. K. D., Dantes, N., \& Parmiti, De. P. (2016). Pengaruh Model Pembelajaran Value Clarification Technique ( Vct ) Terhadap Sikap Sosial Dan Hasil Belajar. E-Jurnal PGSD Universitas Pendidikan Ganesha, 4(1), 1-10.

Selly Lindayani, N. P., Putra, M., \& Manuaba, I. B. S. (2019). Pengaruh Model Pembelajaran Value Clrification Technique Bermuatan Nilai Karakter Terhadap Kompetensi Pengetahuan PPKn. Thinking Skills and Creativity Journal, 2(2), 47.

Siska, Y. (2018). Implementasi Nilai Pendidikan Karakter. Prosiding Seminar Dan Diskusi Pendidikan Dasar, 1, 31-37.

Siswinarti, P. R. (2019). Pengaruh Model Pembelajaran Value Clarification Technique 
Bermediakan Video Terhadap Hasil Belajar Pkn. Jurnal Ilmiah Pendidikan Profesi Guru, 2(1), 1-8.

Sudirman. (2019). Penanaman Nilai dalam Pembelajaran PKN Melalui Inovasi Pendekatan Value Clarification Technique (VCT) di Sekolah. Jurnal IImu Sosial Mamangan, 2(2), 115123.

Suganti, S. (2017). Penerapan Model Pembelajaran Value Clarification Technique Permainan Untuk Meningkatkan Hasil Belajar Pendidikan Kewarganegaraan. Jupiis: Jurnal Pendidikan IImu-IImu Sosial, 9(2), 255.

Sukmawati, E. (2014). Upaya Meningkatkan Hasil Belajar Siswa Melalui Penerapan Model Pembelajaran Quantum Teaching. Jpgsd, 2(3), 11.

Sutiyono, Mahardika, A., \& Gofur, A. (2016). Penguatan Pendidikan Karakter Melalui Values Clarivication Technic (Vct) Dalam Pembelajaran Pkn Berbasis Kearifan Lokal.

Taniredja, T., Faridli, E. M., Harmianto, S. (2017). Model-model Pembelajaran Inovatif dan Efektif. Alfabeta.

Tyas, S. P., \& Mawardi, M. (2016). Keefektifan Model Pembelajaran Value Clarification Technique Dalam Mengembangkan Sikap Siswa. Satya Widya, 32(2), 103. https://doi.org/10.24246/j.sw.2016.v32.i2.p103-116

Wahana, P., \& Mayasari, E. D. (2017). Pengaruh Penerapan Model Pembelajaran Inovatif Pada Matapelajaran Ppkn Terhadap Sikap Siswa Sd Akan Nilai-Nilai Terkait. Jurnal Penelitian, 21, 76-86. 909-2168-1-SM (1).pdf

Wening, S. (2012). Pembentukan Karakter Bangsa Melalui Pendidikan Nilai. Jurnal Pendidikan Karakter, 2(1), 55-66.

Wijayanti, A. T. (2013). Implementasi Pendekatan Values Clarivication Technique (Vct) dalam Pembelajaran IPS di Sekolah Dasar. SOCIA: Jurnal IImu-IImu Sosial, 10(1), 72-79. 